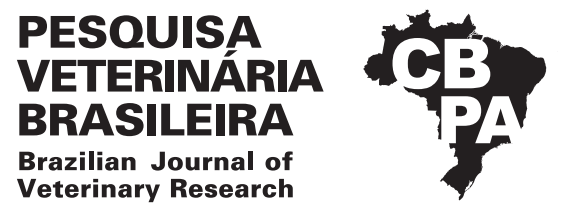

Pesq. Vet. Bras. 39(1):32-39, janeiro 2019 DOI: 10.1590/1678-5150-PVB-6122

Original Article

ISSN 0100-736X (Print)

ISSN 1678-5150 (Online)

\title{
Clinical and pathological aspects of bovine lymphoma affecting the spinal cord ${ }^{1}$
}

\author{
Lauren S. Mello², Welden Panziera², Marcele B. Bandinelli², Luciana Sonne², \\ David Driemeier ${ }^{2}$ and Saulo P. Pavarini'* (D)
}

\begin{abstract}
Mello L.S., Panziera W., Bandinelli M.B., Sonne L., Driemeier D. \& Pavarini S.P. 2019. Clinical and pathological aspects of bovine lymphoma affecting the spinal cord. Pesquisa Veterinária Brasileira 39(1):32-39. Setor de Patologia Veterinária, Faculdade de Veterinária, Universidade Federal do Rio Grande do Sul, Av. Bento Gonçalves 9090, Prédio 42505, Porto Alegre, RS 91540-000, Brazil. E-mail: sauloppvet@yahoo.com.br

Clinical and pathological features of bovine lymphoma involving the spinal cord were evaluated through a retrospective study of the necropsy database from 2005 to 2017. Thirty-four cases of bovine lymphoma were found, 24 of which had central nervous system involvement restricted to the spinal cord. All cattle were Holstein cows 2.5-12 years-old (median age, six years-old). The clinical course was 7-21 days, and the main neurological sign was pelvic limb paresis (81.8\%). The lymphoma often affected the spinal cord in a multifocal manner. Lumbar segments were the mostly affected sites $(23 / 24)$, followed by the sacral segments and cauda equina (20/24), cervical (5/24) and thoracic (5/24) segments. Tumors were in the epidural space, peripheral to the pachymeninges (extradural) and between layers of adipose tissue. In addition, two cases had progressive hemorrhagic myelomalacia. Further organs affected included the lymph nodes $(100 \%)$, abomasum $(79.2 \%)$, heart $(75 \%)$ and kidneys (45.8\%). Microscopically, all lymphomas had a diffuse pattern, with no meningeal or medullar infiltration. According to the REAL/WHO classification, all these neoplasms were mature B-cell lymphomas. Diffuse large B-cell lymphoma (DLBCL) was observed in $95.8 \%(23 / 24)$ of the cases. The following subtypes were observed in the DLBCL group in descending order: immunoblastic $(60.9 \%, 14 / 23)$, centroblastic $(26.1 \%, 6 / 23)$, anaplastic $(8.7 \%, 2 / 23)$ and T-cell rich $(4.3 \%, 1 / 23)$.
\end{abstract}

INDEX TERMS: Clinics, pathology, bovine lymphoma, spinal cord, veterinary neuropathology, paresis, lymphosarcoma, dairy cattle, cattle.

\begin{abstract}
RESUMO.- [Aspectos clínicos e patológicos de linfoma bovino afetando a medula espinhal.] Os aspectos clínicos e patológicos do linfoma bovino afetando a medula espinhal foram avaliados através de um estudo retrospectivo dos protocolos de necropsia durante o período de 2005-2017. De um total de 34 bovinos com linfoma, 24 apresentaram afecção do sistema nervoso central (SNC) restrito a medula espinhal. Todos os bovinos afetados eram fêmeas, da raça Holandesa, com 2,5 a 12 anos de idade (idade mediana de seis anos). Clinicamente, os casos tiveram uma evolução de sete a 21 dias, com a principal alteração neurológica caracterizada por paresia
\end{abstract}

\footnotetext{
${ }^{1}$ Received on September 12, 2018.

Accepted for publication on September 25, 2018.

${ }^{2}$ Setor de Patologia Veterinária, Departamento de Patologia Clínica Veterinária, Faculdade de Veterinária (Favet), Universidade Federal do Rio Grande do Sul (UFRGS), Av. Bento Gonçalves 9090, Prédio 42505, Porto Alegre, RS 91540-000, Brazil. *Corresponding author: saulo.pavarini@ufrgs.br
}

de membros pélvicos, a qual foi observada em $81,8 \%$ dos casos. 0 linfoma afetou frequentemente a medula espinhal de maneira multifocal. Os segmentos lombares foram os mais envolvidos (23/24), seguidos pelos sacrais e cauda equina (20/24), cervicais (5/24) e torácicos (5/24). Os tumores estavam localizados no espaço epidural, periférica à paquimeninge (extradural) e associada ao tecido adiposo. Em dois casos foi também observada mielomalacia hemorrágica progressiva. Os órgãos acometidos com maior frequência, concomitantemente ao espaço epidural, foram os linfonodos (100\%), abomaso $(79,2 \%)$, coração $(75 \%)$ e rins $(45,8 \%)$. Microscopicamente, todos os linfomas exibiam um padrão difuso, sem infiltração em meninges e medula espinhal (extradural). De acordo com a classificação da REAL/WHO, todos esses neoplasmas foram incluídos como linfomas de células B maduras. 0 linfoma difuso de grandes células B (LDGCB) foi observado em 95,8\% (23/24) dos casos. Os subtipos classificados dentro do grupo 
dos LDGCB's foram em ordem decrescente: imunoblástico $(60,9 \% ; 14 / 23)$, centroblástico $(26,1 \% ; 6 / 23)$, anaplásico $(8,7 \% ; 2 / 23)$, e rico em células T $(4,3 \% ; 1 / 23)$.

TERMOS DE INDEXAÇÃO: Clínica, patologia, linfoma bovino, medula espinhal, neuropatologia veterinária, paresia, linfossarcoma, bovino de leite, bovinos.

\section{INTRODUCTION}

Lymphoma encompasses a heterogeneous group of neoplasias originating from lymphoid tissues that have variable clinical, morphological and prognostic presentations (Parodi 2001, Boes \& Durham 2017). Bovine lymphoma has a particular anatomical classification that differs from that of other species of domestic mammals. In general, bovine lymphoma can be divided into two groups: enzootic bovine leukosis (EBL) and sporadic bovine lymphoma (SBL) (Angelos \& Thurmond 2015). The enzootic form is the most common and is an infectious contagious disease of mature cattle associated with bovine leukaemia virus (BLV) (Aida et al. 2013). EBL is predominantly observed in dairy cattle, with a peak incidence between five and eight years of age (Marshak et al. 1962, Vernau et al. 1992). The distribution of EBL is multicentric, since any organ can be involved, and, consequently, clinical signs vary according to tumor site (Burton et al. 2010, Valli et al. 2016). Morphologically, EBL is characterized by monoclonal proliferation of B lymphocytes (Vernau et al. 1997, Yin et al. 2003). There is increasing demand for immunophenotyping of neoplastic lymphocytes to better understand the pathogenesis of the disease (Valli et al. 2017). Lymphoma in animals has numerous similarities with human non-Hodgkin's lymphoma (NHL), and, consequently, most of the classifications used in veterinary medicine were adapted from the human schemes (Sueiro et al. 2004, Ponce et al. 2010, Valli et al. 2011, Vezzali et al. 2010). Among the adapted classifications, the most important and frequently used system for animals is the Revised European-American Classification of Lymphoid Neoplasms (REAL), which was later incorporated into the World Health Organization (WHO) classification (Valli et al. 2016). Although spinal cord involvement is a common presentation of enzootic lymphoma in cattle, there are limited data related to the epidemiological and clinicopathological characterization of this neoplasm in the spinal cord with simultaneous approaches in histological and immunohistochemical (IHC) identification (Valli et al. 2016, 2017). Thus, the aim of this study was to describe the epidemiological, clinical and pathological features of lymphomas with CNS (spinal cord) involvement, in addition to performing a phenotypic and immunophenotypic evaluation of these neoplasms based on the REAL/WHO classification.

\section{MATERIALS AND METHODS}

From January 2005 to January 2017, the necropsy files of cattle with a lymphoma diagnosis were reviewed, and cases with CNS involvement were selected. All cattle studied were from Rio Grande do Sul, Brazil, mainly from Metropolitan Porto Alegre. The protocol information was grouped, registered, and categorized according to age, breed, sex, clinical signs, affected organs and neoplastic distribution in epidural space involving the spinal cord.

Microscopic analysis of lymphomas was performed on histological slides stained with haematoxylin and eosin (HE). This evaluation recorded the distribution pattern of lymphocytes (diffuse and follicular), cell size and mitotic rate. The cell type was characterized based on cell size, nuclei aspect, and characteristics relating to chromatin and to the nucleoli. The mitotic rate was calculated as the mean number of mitoses in 10 high power fields (HPF, 400x). Cell size was based in the average of nuclear diameter and defined as small when the nuclear diameter was equivalent to at most $10 \mu \mathrm{m}$, intermediate when the nuclear diameter was between 10 and $14 \mu \mathrm{m}$ and large when the diameter corresponded to more than $14 \mu \mathrm{m}$ (NCI 1982, Vernau et al. 1992, Valli et al. 2016).

Immunophenotypic analysis of neoplastic lymphocytes was carried out using the REAL/WHO classification adapted for animal use, which is based on morphological and immunophenotypic features (Valli et al. 2016). The immunohistochemical (IHC) analysis was performed using the MACH $4^{\mathrm{TM}}$ Universal AP Polymer Kit (Biocare Medical). Primary antibodies anti-CD79 $\alpha$ (M7051, clone HM57; Dako; 1:100) for B lymphocytes and anti-CD3 (A452; Dako; 1:500) for $\mathrm{T}$ lymphocytes were applied and incubated overnight at $25^{\circ} \mathrm{C}$. To block endogenous peroxidase activity, a $10 \%$ hydrogen peroxide solution was used. Retrieval of the CD79 $\alpha$ antigen was performed in a pressure cooker $\left(96^{\circ} \mathrm{C}, 20 \mathrm{~min}\right)$ with citrate buffer ( $\mathrm{pH} \mathrm{6.0)}$, and Protein Block (Dako) was applied for 7 min to prevent nonspecific binding. For CD3 IHC, the antigen retrieval step was performed with Protease type XIV (Sigma), and milk (15 min) was used to prevent nonspecific binding. Immunoreactivity was visualized by using the chromogens DAB (3,3'-diaminobenzidine) for CD3 IHC and AEC (3-amino-9-ethylcarbazole) for CD79 $\alpha$. Immunohistochemistry sections were counterstained with Harris haematoxylin. Negative control sections were incubated with Tris-buffered saline (TBS) in place of specific antibodies. Tissue sections of bovine tonsils were used as positive controls.

\section{RESULTS}

Thirty-four necropsies of cattle diagnosed with lymphoma were performed during the analysis period, of which 24 (70.6\%) had spinal cord involvement. All cases with CNS involvement corresponded to Holstein females ranging from 2.5 to 12 years-old, with mean and median ages of 5.9 and 6.0 years, respectively.

The most common neurological manifestation was paresis of the pelvic limbs (PL) (81.8\%) (Fig.1A,B), evolving to PL paralysis in $9.1 \%$ of these cases. Tetraparesis was observed in $18.2 \%$ of the cases, with a previous paresis of the thoracic limbs in one of these cases. The reported clinical course of gait alterations ranged from seven to 21 days. The CNS involvement by lymphoma were restricted to the spinal cord. Concerning the anatomic distribution on the spinal cord, tumors proliferation was found in one $(16.7 \%, 4 / 24)$ or more $(83.3 \%, 20 / 24)$ regions. The lumbar region was the most involved (23/24), followed by the sacral/cauda equina (20/24) (Fig.1C), cervical (5/24) and thoracic regions (5/24). Lesions involving more than one region were characterized as multifocal (Fig.1D) or focally extensive lesions, extending from one anatomical location to another. Grossly, the neoplastic masses varied in size, were irregular, soft, and with white or yellow coloration. The masses were in the epidural space, peripheral to the pachymeninges (extradural) and associated with the adipose tissue (Fig.1E). Progressive hemorrhagic myelomalacia was observed in two cases (both affecting the lumbosacral segment) (Fig.1F), of which the grey matter was mainly affected, involving the dorsal and ventral horns. Gross lesions in these cases were characterized by bleeding and soft 

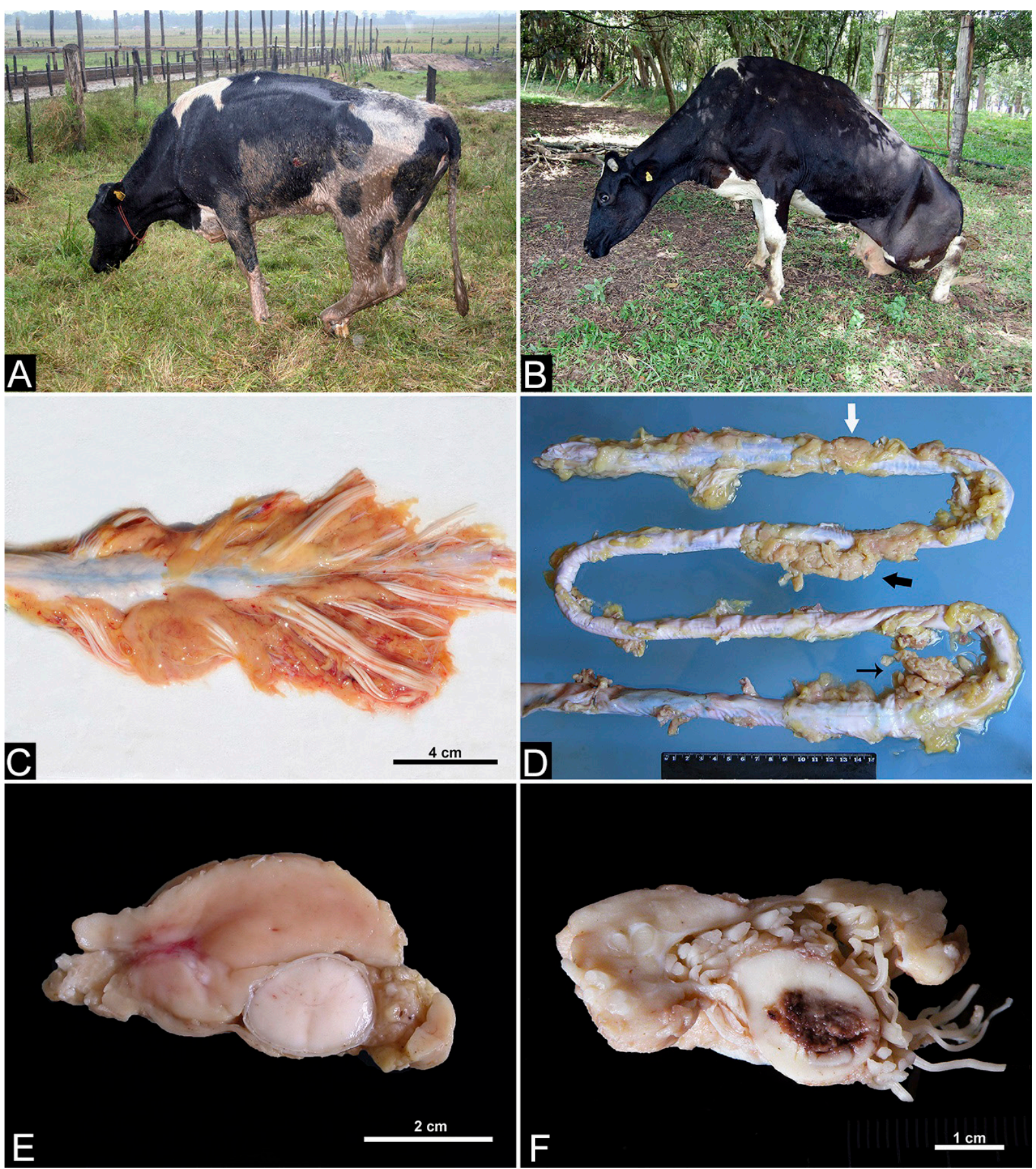

Fig.1. Clinical and gross features of bovine lymphoma in the spinal cord. (A) Thoracolumbar spinal cord compression by lymphoma in a cow causing abnormal posture characterized by arched back, low head carriage and knuckling at the fetlock. (B) Epidural Lumbosacral compression by lymphoma in a cow causing severe pelvic limb paresis. (C) Focally extensive pattern of lymphoma in cervical segments of the spinal cord and cauda equina. (D) Multifocal pattern of lymphoma in the cervical (thin arrow), thoracic (black arrow) and lumbar (white arrow) segments of the spinal cord. (E) Lumbar spinal cord. Extradural pattern of bovine lymphoma. (F) Sacral spinal cord. Hemorrhagic myelomalacia due to extradural lymphoma.

areas, in addition to occasional cavitation. Other organs were simultaneously affected in all cases of bovine lymphoma with spinal cord involvement. Among the main sites of neoplastic localization, the most common were the lymph nodes $(100 \%$, $24 / 24)$, abomasum $(79.2 \%, 19 / 24)$, heart $(75 \%, 18 / 24)$ and kidneys (45.8\%, 11/24).
Histologic evaluation revealed a diffuse pattern of neoplastic cells distribution with an extradural predominance, without infiltration in the meninges and spinal cord. All the lymphoma cases in this study demonstrated cytoplasmic immunostaining for the $\mathrm{CD} 79 \alpha$ antibody, identifying lymphocytes as the B immunophenotype. According to the REAL/WHO 
classification criteria, all these neoplasms were mature B-cell lymphomas (Fig.2A). Within this large group, 95.8\% (23/24) of cases were classified as diffuse large B-cell lymphoma (DLBCL). The subtypes within the DLBCL group included immunoblastic $(60.9 \%, 14 / 23)$, centroblastic $(26.1 \%, 6 / 23)$, anaplastic $(8.7 \%, 2 / 23)$, and T-cell rich $(4.3 \%, 1 / 23)$.

Immunoblastic DLBCLs were predominantly composed of large cells with round euchromatic nuclei (approximately 14.0-17.5 $\mu \mathrm{m}$ ), vesicular or coarsely granular chromatin, a single central nucleolus and scant cytoplasm (Fig.2B). The mitotic rate per 400x HPF ranged from two to eight figures, and the mean mitotic rate was 3.4. Centroblastic DLBCLs were characterized by large oval cells with scant cytoplasm. The nuclei size (10.5-17.5 $\mu \mathrm{m})$ and shape were highly variable, ranging from round to indented (cleaved) and exhibiting vesicular or coarsely granular chromatin and multiple nucleoli that appeared associated with the nucleolemma (Fig.2C). The mean mitotic rate (HPF, 400x) was 6.3 (range, two to 12). Anaplastic DLBCLs were composed of pleomorphic cells of varying sizes, occasionally with bizarre nuclei, and frequent multinucleation (Fig.2D). The mitotic figures were higher, with a mean mitotic rate of 6 (HPF, 400x). Generally, most of the cells were large, with a nuclear size of approximately 21 to $28 \mu \mathrm{m}$. T-cell rich DLBCL was characterized by heterogeneous cellular patterns and the presence of small and large lymphocytes. Most of the cells (approximately 80\%) were small non-neoplastic $\mathrm{T}$ cells that showed positive immunostaining for CD3. The large neoplastic cells (approximately 20\%) were of the B immunophenotype and had approximately two mitotic figures (HPF). The nuclei had one or more evident nucleoli, dispersed chromatin and moderate basophilic cytoplasm. In high mitotic rate lymphomas (20.8\%), interspersed macrophages filled by apoptotic lymphocytes (tingible body macrophages) resembling a "starry-sky" were observed.

Small lymphocytic B-cell lymphoma, also termed mature (peripheral) B-cell neoplasia, was observed in one case (4.2\%). This lymphoma was composed of small lymphocytes with scant cytoplasm, round nuclei (approximately $7 \mu \mathrm{m}$ ), dense chromatin and inconspicuous nucleoli. One mitotic figure (HPF) was observed. Spinal cord injuries secondary to enzootic lymphoma involvement in the epidural space were observed in $54.2 \%$ of the cases. These lesions resulted in compression by the extradural tumor masses and consisted mainly of Wallerian degeneration with the formation of

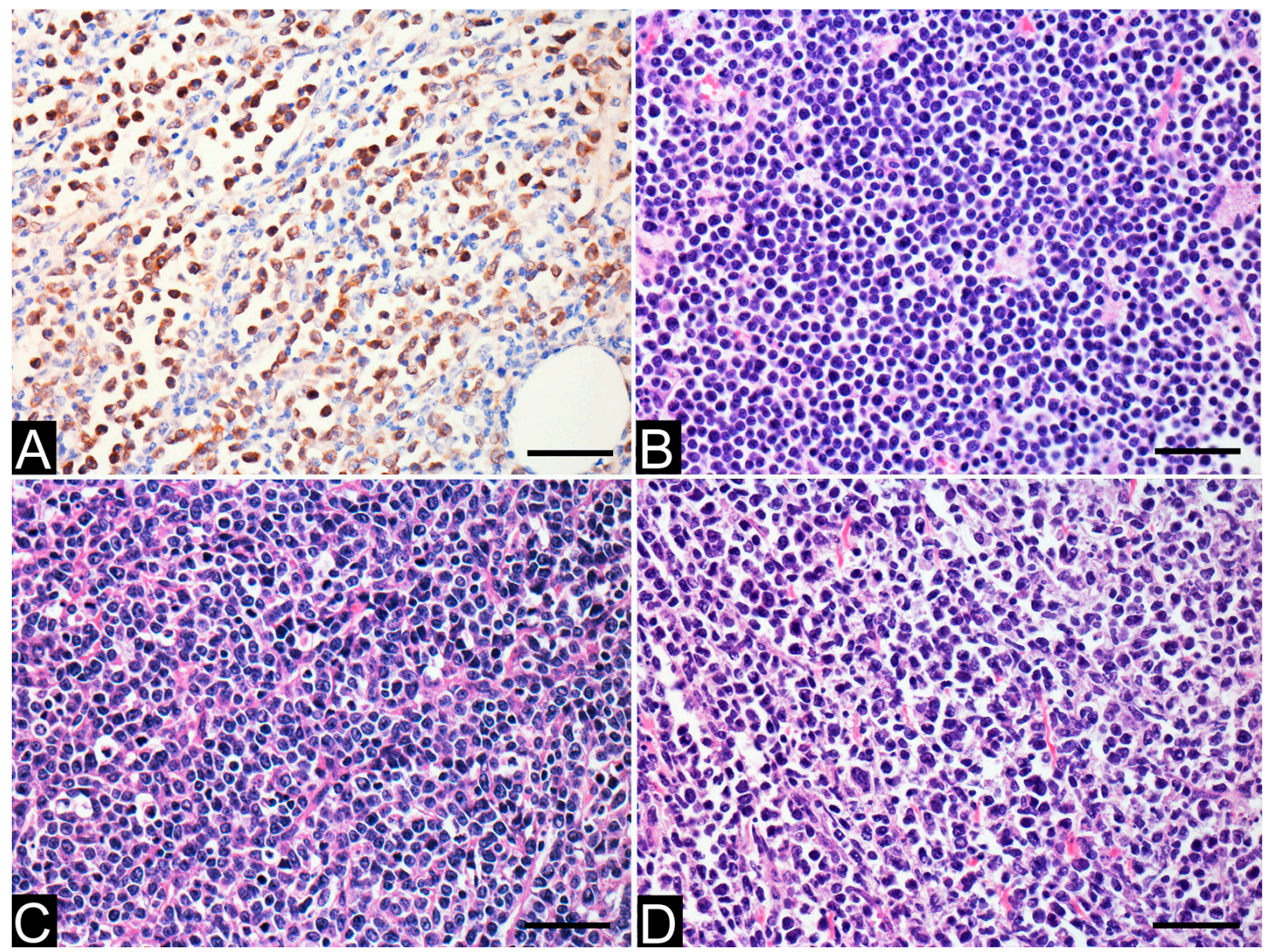

Fig.2. Microscopic features of bovine lymphoma in the spinal cord. (A) Epidural mass, positive cytoplasmic staining of neoplastic lymphocytes. IHC for CD79 $\alpha$, bar $=100 \mu \mathrm{m}$. (B) Diffuse large B-cell lymphoma, immunoblastic variant. Sheets of large cells with round, euchromatic nuclei. HE, bar $=100 \mu \mathrm{m}$. (C) Diffuse large B-cell lymphoma, centroblastic variant. Sheets of large cells with highly variable nuclei ranging from round to indented (cleaved) and frequently with multiple nucleoli. HE, bar $=100 \mu \mathrm{m}$. (D) Diffuse large B-cell lymphoma, anaplastic variant. Sheets of pleomorphic large cells with bizarre nuclear features. HE, bar $=100 \mu \mathrm{m}$. 
axonal spheroids. Hemorrhagic myelomalacia $(8.3 \%, 2 / 24)$ was observed in the lumbosacral portion. This lesion was found predominantly in grey matter and was characterized by extensive hemorrhagic areas, neutrophilic vasculitis, gitter cell infiltrate and malacia. Necrotic neurons showed retraction, a hypereosinophilic cytoplasm and pyknotic nuclei. In the remaining white matter, axonal spheroids, Wallerian degeneration and neutrophil infiltration were observed.

\section{DISCUSSION}

Bovine lymphoma is the most common neoplasm in milk-producing regions and is an important cause of economic loss in this industry in several parts of the world (Jacobs et al. 2002, Trainin \& Brenner 2005). This neoplasm was appointed as one of the main causes of death in dairy cows in southern Brazil, in addition to being the most frequent neoplastic disease (Mello et al. 2017). All the cattle studied were adult and presented a multicentric distribution of lymphoma. Although were not performed tests for BLV detection, according to the epidemiological data, clinical and anatomopathological presentation in this study all cases were consistent with the adult, or enzootic form of lymphoma (Angelos \& Thurmond 2015, Valli et al. 2016). This form is known to be associated with BLV infection and the frequent presentation occur in age groups older than two years, with a peak incidence between four and eight years as seem in the cattle studied (Vernau et al. 1992, Schwartz \& Levy 1994, Kabeya et al. 2001). In this study, female dairy cattle were the most likely to be affected by lymphoma. The high prevalence in dairy cows was mainly associated with longevity and intensive practices that favor the spread of BLV (Hopkins \& Digiacomo 1997, Kobayashi et al. 2010). The predominance among females is an expected feature due to a lower proportion of males in dairy herds (Marshak et al. 1962). Furthermore, the higher susceptibility in females may also be associated with the immunosuppressive role of physiological stress generated by the high demand for milk production (Wu et al. 1989). Studies have shown potential genetic susceptibility as a predisposing factor in the development of lymphoma in some herds (Jacobs et al. 2002, Aida et al. 2013, Angelos \& Thurmond 2015). Beef cattle, which were not affected in this study, are usually less affected due to the long course of the illness and the less intensive handling techniques employed (Jacobs et al. 2002, Radostits et al. 2007, Angelos \& Thurmond 2015).

Extradural lymphoma in cattle is a common presentation of this multicentric illness in addition to being the main compressive neoplasm in this species (Ferrer 1980, Rebhun et al. 1984, Sherman 1987, Jacobs et al. 2002, Lahunta \& Divers 2008, Burton et al. 2010). As has been frequently reported in studied cattle, locomotor disorders of the hind limbs (paresis and paralysis) are a common neurologic manifestation resulting from tumor compression in the lumbosacral region, which is the most common site of neoplastic infiltration (Lahunta \& Divers 2008, Lahunta \& Glass 2009, Angelos \& Thurmond 2015, Washburn 2017). The clinical signs of tetraparesis and paresis of thoracic limbs related to medullary compression in the craniocervical and caudal cervical regions were less common due to the low frequency of tumor masses in these regions (Lahunta \& Glass 2009). Vertebral bone infiltration by lymphoma was not observed in any of the cases; such infiltration is rare and is observed mainly in young cattle with the sporadic form (Theilen \& Dungworth 1965, Bundza et al. 1980, Oliver-Espinosa et al. 1994). Brain involvement in cases of bovine lymphoma may occur; however, it is considered uncommon (Sweeney et al. 1986, Sherman 1987, Fighera \& Barros 2004, Braun et al. 2005, Tawfeeq et al. 2012), and it was not observed in the present study. The pathogenesis of extradural lymphoma remains uncertain. Despite the controversial presence of lymphoid tissue around the epidural venous plexus, lymphoma on the spinal canal may originate primarily from this location (Love et al. 1954). However, lymphoma that establishes in this area may originate elsewhere in a systemic disease. It has been previously observed that the propagation may occur through the paravertebral region to the inside of the canal by the intervertebral foramen (Cugati et al. 2011). Therefore, tumor masses may be observed around paravertebral structures, such as spinal vessels and nerves (Mullins et al. 1971, Valli et al. 2016). Another suggested origin is neoplastic lymphocyte infiltration through hematogenous spread through the epidural venous plexus, which is an important route of neoplasm establishment in this region (Harrington 1986, Maccauro et al. 2011). The epidural venous plexus, which contains multiple epidural vessels, is characterized by a venous net with thin walls lacking valves and muscular fibers (Batson 1957, Dyce et al. 2010). The connections of this system with thoracic, abdominal and pelvic veins allow for retrograde flow to the interior of the vertebral spine when the pressure increases in these cavities (Batson 1940). In an experiment in rats and rabbits, $70 \%$ of cases showed tumor development in the lumbar region after tumor cell injection in the femoral vein and abdominal pressure elevation (Coman \& Delong 1951).

The hemorrhagic myelomalacia observed in two cattle in this study represents a neurovascular disorder secondary to compressive medullar injury (Lahunta \& Glass 2009). This alteration occurs frequently in dogs and is usually associated with extramedullary pressure, as in intervertebral disc disease (Lahunta \& Glass 2009). Lymphoma as a cause of hemorrhagic myelomalacia was previously described in horses (Rousseaux et al. 1989), cats (Laisse et al. 2017) and dogs (Zilio \& Arias 2013), but to the best of our knowledge, there have been no reports in cattle. The hemodynamic disturbances caused by epidural compression generate vascular stasis, blood perfusion failure, plasma protein extravasation, increased colloid osmotic pressure and consequent edema (Vandevelde et al. 2012). Spinal cord lesions resulted from the cumulative effect of these pathological processes associated with inflammatory mediators that provoke vasospasm (Mautes et al. 2000). Moreover, the grey matter tends to be severely affected compared to the white matter due to the high metabolic rate (Risio \& Platt 2010), as observed in the cases studied here.

According to the REAL/WHO classification criteria, all lymphomas in this study were mature B-cell lymphomas. Within this wide group, DLBCL was the more common sub-classification, accounting for approximately $95 \%$ of tumors. This subtype is the main type of lymphoma in cattle and usually presents as the enzootic form (Vernau et al. 1992, 1997, Panziera et al. 2014, 2016). This type of lymphoma is an aggressive and rapidly growing tumor. In addition to being more commonly observed affecting the lymph nodes, it can 
be found in any tissue (Valli et al. 2016). The pathogenesis of BLV regarding the specific development of this type of lymphoma has not been completely elucidated. It is known that this virus provokes a clonal proliferation of B-cells, and disease severity increases according to the number of pro-viral copies (Aida et al. 2013). High proliferative rates induced by BLV may be responsible for the loss of differentiation, thus explaining the low occurrence of follicular lymphoma in cattle (Vernau et al. 1992). Although viral involvement is not a premise for the development of DLBCL, the occurrence of this disease has been related to viral agents in other species. Lymphomas can be associated with feline leukemia virus (FeLV) and feline immunodeficiency virus (FIV) in cats and with Epstein-Barr virus (EBV) and hepatitis C virus (HCV) in humans (Callanan et al. 1996, Hoeller et al. 2010, Visco \& Finotto 2014, Valli et al. 2017). In dogs, DLBCL represents approximately $50 \%$ of lymphomas, mainly constituted by the centroblastic subtype and less frequently by the immunoblastic type (Valli et al. 2011, Vezzali et al. 2010). In contrast to what is seen in dogs, the immunoblastic type was more frequently observed than the centroblastic type in cattle in this study. However, these two subtypes show no clinical or therapeutic differences because they are morphological variants that can coexist inside the same neoplasm (Valli et al. 2016). Anaplastic lymphoma is one of the DLBCL subtypes that is less frequently observed in different species (Valli et al. 2017). In humans, this subtype is more aggressive than anaplastic T-cell lymphoma (Weisenburger et al. 2001). In the studied cattle, the T-cell rich subtype of DLBCL was the least frequent; however, this subtype is the most common in horses, accounting for approximately half of the lymphomas (Durham et al. 2013).

\section{CONCLUSIONS}

Compression of the spinal cord is the main site of compromise in cases of central nervous system lymphoma. Adult dairy cows are mainly affected and hind limb paresis is the main clinical sign.

Epidural sites are the main location of tumors which are associated with the extradural adipose tissue. Distribution of tumors is mainly multifocal and lumbar and sacral regions were most affected.

According to the WHO/REAL criteria, all extradural lymphomas were classified as mature B-cell lymphomas, and diffuse large B-cell lymphomas were the most common.

Acknowledgments.- The authors thank the Conselho Nacional de Desenvolvimento Científico e Tecnológico (CNPq) and Coordenação de Aperfeiçoamento de Pessoal de Nível Superior (CAPES) for supporting this study.

Conflict of interest statement.- The authors declare no conflict of interest with respect to the publication of this paper.

\section{REFERENCES}

Aida Y., Murakami H., Takahashi M. \& Takeshima S.-N. 2013. Mechanisms of pathogenesis induced by bovine leukemia virus as a model for human T-cell leukemia virus. Front. Microbiol. 4:328. <http://dx.doi.org/10.3389/ fmicb.2013.00328><PMid:24265629>

Angelos J.A. \& Thurmond M.C. 2015. Bovine lymphoma, p.1070-1073. In: Smith B.P. (Ed), Large Animal Internal Medicine. 5th ed. Elsevier, St Louis.
Batson O.V. 1940. The function of the vertebral veins and their role in the spread of metastases. Annals Surg. 112(1):138-149. <http://dx.doi. org/10.1097/00000658-194007000-00016><PMid:17857618>

Batson O.V. 1957. The vertebral veins system. Am. J. Roentgenol. 78:195-212.

Boes K.M. \& Durham A.C. 2017. Bone marrow, Blood cells, and the lymphatic system/lymphoid system, p.724-804. In: Zachary J.F. (Ed.), Pathologic Basis of Veterinary Disease. 6th ed. Elsevier, St Louis. 794p. <http://dx.doi. org/10.1016/B978-0-323-35775-3.00013-8>.

Braun U., Jehle W. \& Soldati G. 2005. Malignant cerebellar lymphoma in a calf. Vet. Rec. 156(7):215-216. <http://dx.doi.org/10.1136/vr.156.7.215> $<$ PMid:15747662>

Bundza A., Greig A.S., Chander S. \& Dukes T.W. 1980. Sporadic bovine leukosis: a description of eight calves received at Animal Diseases Research Institute from 1974-1980. Can. Vet. J. 21(10):280-283. <PMid:6254627>

Burton A.J., Nydam D.V., Long E.D. \& Divers T.J. 2010. Signalment and clinical complaints initiating hospital admission, methods of diagnosis, and pathological findings associated with bovine lymphosarcoma, 112 cases. J. Vet. Intern. Med. 24(4):960-964.<http://dx.doi.org/10.1111/j.1939-1676.2010.0537. $\mathrm{x}><$ PMid:20492490>

Callanan J.J., Jones B.A., Irvine J., Willett B.J., McCandlish I.A. \& Jarrett O. 1996. Histologic classification and immunophenotype of lymphosarcomas in cats with naturally and experimentally acquired feline immunodeficiency virus infections. Vet. Pathol. 33(3):264-272. <http://dx.doi. org/10.1177/030098589603300302><PMid:8740699>

Coman D.R. \& Delong R.P. 1951. The role of the vertebral venous system in the metastasis of cancer to the spinal column; experiments with tumorcell suspensions in rats and rabbits. Cancer 4(3):610-618. <http://dx.doi. org/10.1002/1097-0142(195105)4:3<610::AID-CNCR2820040312>3.0.C0;2-Q> <PMid:14839615>

Cugati G., Singh M., Pande A., Ramamurthi R., Balasubramanyam M., Sethi S.K. \& Singh A.K. 2011. Primary spinal epidural lymphomas. J. Craniovertebral Junction Spine 2(1):3-11. <http://dx.doi.org/10.4103/0974-8237.85307> <PMid:22013369>

Durham A.C., Pillitteri C.A., Myint M.S. \& Valli V.E. 2013. Two hundred three cases of equine lymphoma classified according to the World Health Organization (WHO) classification criteria. Vet. Pathol. 50(1):86-93. <http://dx.doi.org/10.1177/0300985812451603><PMid:22700849>

Dyce K.M., Sack W.O. \& Wensing C.J.G. 2010. The nervous system, p.311-314. In: Ibid. (Eds), Textbook of Veterinary Anatomy. 4th ed. W.B. Saunders, St Louis.

Ferrer J.F. 1980. Bovine lymphosarcoma. Adv. Vet. Sci. Comp. Med. 24:1-68. $<$ PMid:6257088>

Fighera R.A. \& Barros C.S.L. 2004. Intracerebral lymphosarcoma in a cow. Ciência Rural 34(3):943-945. <http://dx.doi.org/10.1590/S010384782004000300046>

Harrington K.D. 1986. Metastatic disease of the spine. J. Bone Joint Surg. 68(7):1110-1115. <http://dx.doi.org/10.2106/00004623-19866807000025><PMid:3745256>

Hoeller S., Tzankov A., Pileri S.A., Went P. \& Dirnhofer S. 2010. Epstein-Barr virus-positive diffuse large B-cell lymphoma in elderly patients is rare in Western populations. Hum. Pathol. 41(3):352-357. <http://dx.doi. org/10.1016/j.humpath.2009.07.024><PMid:19913281>

Hopkins S.G. \& Digiacomo R.F. 1997. Natural transmission of bovine leukemia virus in dairy and beef cattle. Vet. Clin. N. Am., Food Anim. Pract. 13(1):107-128. <http://dx.doi.org/10.1016/S0749-0720(15)30367-4> $<$ PMid:9071749>

Jacobs R.M., Messick J.B. \& Valli V.E. 2002. Tumors of the hemolymphatics system, p.128-161. In: Meuten D.J. (Ed), Tumors in Domestic Animals. 4th ed. Iowa State Press, Iowa. 
Kabeya H., Ohashi K. \& Onuma M. 2001. Host immune responses in the course of bovine leukemia virus infection. J. Vet. Med. Sci. 63(7):703-708. <http:// dx.doi.org/10.1292/jvms.63.703><PMid:11503896>

Kobayashi S., Tsutsui T., Yamamoto T., Hayama Y., Kameyama K., Konishi M. \& Murakami K. 2010. Risk factors associated with within-herd transmission of bovine leukemia virus on dairy farms in Japan. BMC Vet. Res. 6(1):1-6. <http://dx.doi.org/10.1186/1746-6148-6-1><PMid:20055982>

Lahunta A. \& Divers T.J. 2008. Neurologic diseases, p.504-560. In: Ibid. (Eds), Rebhun's Diseases of Dairy Cattle. 2th ed. Elsevier, St Louis. <http://dx.doi. org/10.1016/B978-141603137-6.50015-6>.

Lahunta A. \& Glass E. 2009. Large animal spinal cord diseases, p.288-289. In: Ibid. (Eds), Veterinary Neuroanatomy and Clinical Neurology. 3th ed. W.B. Saunders, St Louis.

Laisse C.J.M., Oliveira E.C., Rolim V.M., Negreiros D.O., Driemeier D. \& Pavarini S.P. 2017. Haemorrhagic myelomalacia in a cat with extradural T-cell lymphoma. Semina, Ciênc. Agrárias 38:327-334.

Love J.G., Miller R.H. \& Kernohan J.W. 1954. Lymphomas of spinal epidural space. Arch. Surg. 69(1):66-76. <http://dx.doi.org/10.1001/ archsurg.1954.01270010068010 > <PMid:13170925>

Maccauro G., Spinelli M.S., Mauro S., Perisano C., Graci C. \& Rosa M.A. 2011. Physiopathology of spine metastasis. Int. J. Surg. Oncol. 2011:107969. <http://dx.doi.org/10.1155/2011/107969> <PMid:22312491>

Marshak R.R., Coriell L.L., Lawrence W.C., Croshaw Jr J.E., Schryver H.F., Altera K.P. \& Nichols W.W. 1962. Studies on bovine lymphosarcoma. I. Clinical aspects, pathological alterations, and herd studies. Cancer Res. 22:202-217. <PMid:14470234>

Mautes A.E.M., Weinzierl M.R., Donovan F. \& Noble L.J. 2000. Vascular events after spinal cord injury: contribution to secondary pathogenesis. Phys. Ther. 80(7):673-687. <PMid:10869130>

Mello L.S., Bianchi M.V., Bandinelli M.B., Sonne L., Driemeier D. \& Pavarini S.P. 2017. Causas de morte em vacas leiteiras no Rio Grande do Sul. Pesq. Vet. Bras. 37(9):916-920. <http://dx.doi.org/10.1590/s0100-736x2017000900003>

Mullins G.M., Flynn J.P., el-Mahdi A.M., McQueen J.D. \& Owens Jr A.H. 1971. Malignant lymphoma of the spinal epidural space. Ann. Intern. Med. 74(3):416-423. <http://dx.doi.org/10.7326/0003-4819-74-3-416> <PMid:4928162>

NCI 1982. National Cancer Institute sponsored study of classification of nonHodking's lymphomas: summary and description of a working formulation for a clinical usage: the non-Hodgkin's lymphoma pathologic classification project. Cancer 49(10):2112-2135. <http://dx.doi.org/10.1002/10970142(19820515)49:10<2112::AID-CNCR2820491024>3.0.CO;2-2> <PMid:6896167>

Oliver-Espinosa O., Physick-Sheard P.W., Wollenberg G.K. \& Taylor J. 1994. Sporadic bovine leukosis associated with ataxia and tibiotarsal joint swelling: a case report. Can. Vet. J. 35(12):777-779. <PMid:9132289>

Panziera W., Bianchi R.M., Galiza G.J.N., Pereira P.R., Mazaro R.D., Barros C.S.L., Kommers G.D., Irigoyen L.F. \& Fighera R.A. 2014. Aspectos epidemiológicos, clínicos e anatomopatológicos do linfoma em bovinos: 128 casos (19652013). Pesq. Vet. Bras. 34(9):856-864. <http://dx.doi.org/10.1590/ S0100-736X2014000900009>

Panziera W., Bianchi R.M., Faccin T.C., Galiza G.J.N., Lopes E.M.B., Kommers G.D. \& Fighera R.A. 2016. Classificação de 86 casos de linfoma em bovinos de acordo com a Working Formulation (WF) of Non-Hodgkin's lymphomas for clinical usage e a revised European-American classification of lymphoid neoplasms (REAL). Pesq. Vet. Bras. 36(4):263-271. <http://dx.doi. org/10.1590/S0100-736X2016000400003>

Parodi A.L. 2001. Classification of malignant lymphoma in domestic animals: history and conceptual evolution. European J. Vet. Pathol. 7:43-50.

Ponce F., Marchal T., Magnol J.P., Turinelli V., Ledieu D., Bonnefont C., Pastor M., Delignette M.L. \& Fournel-Fleury C. 2010. A morphological study of 608 cases of canine malignant lymphoma in France with a focus on comparative similarities between canine and human lymphoma morphology. Vet. Pathol.47(3):414-433.<http://dx.doi.org/10.1177/0300985810363902> <PMid:20472804>

Radostits M.O., Gay C.C., Hinchcliff K.W. \& Constable P.D. 2007. Diseases associated with viruses and Chlamydia, p.1209-1221. In: Ibid. (Eds), Veterinary Medicine: a textbook of the diseases of cattle, horses, sheep, pigs and goats. 10th ed. Elsevier, Philadelphia.

Rebhun W.C., De Lahunta A., Baum K., King J. \& Roth L. 1984. Compressive neoplasms affecting the bovine spinal cord. Compend. Contin. Educ. Vet. 6:396-400

Risio L. \& Platt S.R. 2010. Fibrocartilaginous embolic myelopathy in small animals. Vet. Clin. N. Am., Small Anim. Pract. 40(5):859-869. <http://dx.doi. org/10.1016/j.cvsm.2010.05.003><PMid:20732595>

Rousseaux C.G., Doige C.E. \& Tuddenham T.J. 1989. Epidural lymphosarcoma with myelomalacia in a seven-year-old Arabian gelding. Can. Vet. J. 30(9):751-753. <PMid:17423424>

Schwartz I. \& Levy D. 1994. Pathobiology of bovine leukemia virus. Vet. Res. 25(6):521-536. <PMid:7889034>

Sherman D.M. 1987. Localized diseases of the bovine brain and spinal cord. Vet. Clin. N. Am., Food Anim. Pract. 3(1):179-191. <http://dx.doi. org/10.1016/S0749-0720(15)31189-0><PMid:3494493>

Sueiro F.A.R., Alessi A.C. \& Vassallo J. 2004. Canine lymphomas: a morphological and immunohistochemical study of 55 cases, with observations on p.53 immunoexpression. J. Comp. Pathol. 131(2/3):207-213. <http://dx.doi. org/10.1016/j.jcpa.2004.04.002 > <PMid:15276860>

Sweeney R.W., Divers T.J., Ziemer E. \& Lichtensteiger C.A. 1986. Intracranial lymphosarcoma in a Holstein bull. J. Am. Vet. Med. Assoc. 189(5):555-556. <PMid:3759627>

Tawfeeq M.M., Miura S., Sugimoto K., Kobayashi Y. \& Inokuma H. 2012. Thymic lymphosarcoma with brain involvement in a holstein heifer. Am. Vet. Med. Assoc. 74(11):1501-1504.<PMid:22785125>

Theilen G.H. \& Dungworth D.L. 1965. Bovine lymphosarcoma in California. III. The calf form. Am. Vet. Med. Assoc. 26:696-709. <PMid:14316787>

Trainin Z. \& Brenner J. 2005. The direct and indirect economic impacts of bovine leukemia virus infection on dairy cattle. Isr. J. Vet. Med. 60:94-105.

Valli V.E., Kiupel M. \& Bienzle D. 2016. Hematopoietic system, p.107-324. In: Maxie G.M. (Ed.), Jubb, Kennedy, and Palmer's Pathology of Domestic Animals. 6th ed. Elsevier, St Louis. <http://dx.doi.org/10.1016/B978-07020-5319-1.00013-X>

Valli V.E., Bienzle D. \& Meuten D.J. 2017. Tumors of the hemolymphatic system, p.203-321. In: Meuten D.J. (Ed.), Tumors in Domestic Animals. 5th ed. John Wiley and Sons, Iowa.

Valli V.E., Myint M.S., Barthel A., Bienzle D., Caswell J., Colbatzky F., Durham A., Ehrhart E.J., Johnson Y., Jones C., Kiupel M., Labelle P., Lester S., Miller M., Moore P., Moroff S., Roccabianca P., Ramos-Vara J., Ross A., Scase T., Tvedten H. \& Vernau W. 2011. Classification of canine malignant lymphomas according to the World Health Organization criteria. Vet. Pathol. 48(1):198211. <http://dx.doi.org/10.1177/0300985810379428><PMid:20861499>

Vandevelde M., Higgins R.J. \& Oevermann A. 2012. Trauma, p.83-84. In: Ibid. (Eds), Veterinary Neuropathology: essentials of theory and practice. Wiley-Blackwell, Chichester, UK.

Vernau W., Valli V.E., Dukes T.W., Jacobs R.M., Shoukri M. \& Heeney J.L. 1992. Classification of 1,198 cases of bovine lymphoma using the National Cancer Institute Working Formulation for human non-Hodgkin's lymphomas. Vet. Pathol. 29(3):183-195.<http://dx.doi.org/10.1177/030098589202900301> <PMid:1621329>

Vernau W., Jacobs R.M., Valli V.E. \& Heeney J.L. 1997. The immunophenotypic characterization of bovine lymphomas. Vet. Pathol.34(3):222-225.<http:// dx.doi.org/10.1177/030098589703400307> <PMid:9163878> 
Vezzali E., Parodi A.L., Marcato P.S. \& Bettini G. 2010. Histopathologic classification of 171 cases of canine and feline non-Hodgkin lymphoma according to the WHO. Vet. Comp. Oncol. 8(1):38-49. <http://dx.doi. org/10.1111/j.1476-5829.2009.00201.x ><PMid:20230580>

Visco C. \& Finotto S. 2014. Hepatitis C virus and diffuse large B-cell lymphoma: pathogenesis, behavior and treatment. World J. Gastroenterol. 20(32):1105411061. <http://dx.doi.org/10.3748/wjg.v20.i32.11054><PMid:25170194>

Washburn K.E. 2017. Localization of neurologic lesions in ruminants. Vet. Clin. N. Am., Food Anim. Pract. 33(1):19-25. <http://dx.doi.org/10.1016/j. cvfa.2016.09.003><PMid:27914745>

Weisenburger D.D., Anderson J.R., Diebold J., Gascoyne R.D., MacLennan K.A., Müller-Hermelink H.K., Nathwani B.N., Ullrich F. \& Armitage J.O. 2001. Systemic anaplastic large-cell lymphoma: results from the non-Hodgkin's lymphoma classification project. Am. J. Hematol. 67(3):172-178. <http:// dx.doi.org/10.1002/ajh.1102><PMid:11391714>

Wu M.C., Shanks R.D. \& Lewin H.A. 1989. Milk and fat production in dairy cattle influenced by advanced subclinical bovine leukemia virus infection. Proc. Natl Acad. Sci. USA 86(3):993-996. <http://dx.doi.org/10.1073/ pnas.86.3.993 $><$ PMid:2536940>

Yin S.A., Makara M., Pan Y., Ishiguro H., Ikeda M., Numakunai S., Goryo M. \& Okada K. 2003. Relation between phenotype of tumor cells and clinicopathology in bovine leukosis. J. Vet. Med. Sci. 65(5):599-606. <http:// dx.doi.org/10.1292/jvms.65.599><PMid:12808212>

Zilio D.M. \& Arias M.V.B. 2013. Mielomalacia hemorrágica progressiva em 14 cães. Pesq. Vet. Bras. 33(2):219-228. <http://dx.doi.org/10.1590/ S0100-736X2013000200014> 